\title{
Utilities reforms and corruption in developing countries ${ }^{1}$
}

\author{
Antonio Estache \\ The World Bank and \\ ECARES, Université Libre de Bruxelles
}

Ana Goicoechea

The World Bank

Lourdes Trujillo

Universidad de Las Palmas de Gran Canaria and

Center for Regulation and Competition Policy, City University London

\begin{abstract}
This paper shows empirically that "privatization" in the energy, telecommunications, and water sectors, and the introduction of independent regulators in those sectors, have not always had the expected effects on access, affordability, or quality of services. It also shows that corruption leads to adjustments in the quantity, quality, and price of services consistent with the profit-maximizing behavior that one would expect from monopolies in the sector. Finally, our results suggest that privatization and the introduction of independent regulators have, at best, only partial effects on the consequences of corruption for access, affordability, and quality of utilities services.
\end{abstract}

World Bank Policy Research Working Paper 4081, December 2006

The Policy Research Working Paper Series disseminates the findings of work in progress to encourage the exchange of ideas about development issues. An objective of the series is to get the findings out quickly, even if the presentations are less than fully polished. The papers carry the names of the authors and should be cited accordingly. The findings, interpretations, and conclusions expressed in this paper are entirely those of the authors. They do not necessarily represent the view of the World Bank, its Executive Directors, or the countries they represent. Policy Research Working Papers are available online at http://econ.worldbank.org.

\footnotetext{
${ }^{1}$ The authors are grateful for the insights and suggestions of Daniel Benitez, Cecilia Briceno, Claude Crampes, Mathias Dewatripont, Katharina Gassner, Jose-Luis Guasch, Paul Grout, Charles Kenny, Lazlo Lovei, Marco Manacorda, Martin Rodriguez-Pardina, Stephane Saussier, and Stephane Straub, and of participants in seminars at the University of Bristol, the Université Libre de Bruxelles, the Universite des Sciences Sociales de Toulouse, the French State Council, and the U.K. Department for International Development.
} 


\section{Introduction}

Utility reform has been a common feature of developing countries' economic adjustment programs since the early 1990s. While the reforms have covered a wide range of policy areas, their most visible dimensions, and certainly the most debated, have been: (i) the increased autonomy of regulators of the sector, (ii) an increased role for the private sector in the delivery of infrastructure services, and (iii) the opening of infrastructure markets to competition. The main motivation for reform was often the need to cut fiscal deficits rather than a concern for performance. However, reformers also promised improved efficiency and social benefits, such as wider access, more affordable services, and better service quality.

A lower level of corruption in the sector was another expected benefit. That expectation was supported by the theoretical modeling of corruption as the "nonbenevolence of government" by authors such as Shapiro and Willig (1990), Shleifer and Vishny (1993), and Boycko, Shleifer, and Vishny (1996). Their intuition was that privatization could reduce the control of government over the rents offered by the direct operation of public services. ${ }^{2}$ For utilities, the message from this research was simple. Privatize as soon as possible and increase the independence of regulation of public and private monopolistic operators to increase their transparency. Doing so would increase the political accountability of the regulatory role and thereby reduce corruption.

Now, 15 years after the first large-scale utilities reforms were launched, the pendulum is swinging back. The value of private sector participation and of regulation at arms length no longer appears to be favored by newly elected governments, often with the support of their electorate, in developing countries. Critics of the 1990s reforms currently dominate the media with a plethora of anecdotes pointing to reform failures, including a large number that suggest that corruption remains a problem in the sector.

At this turning point in political support for past reforms, it seems useful to try to get a quantitative sense of what the reforms actually achieved in developing countries. There is little quantitative, cross-country evidence in the literature. Most cross-country studies deal with specific aspects of reform; studies that consider all dimensions of reforms jointly, on the other hand, tend to focus on specific countries. A few crosscountry studies have focused on a single sector-generally telecommunications but occasionally electricity or water. ${ }^{3}$ There is also a large literature on the effects of privatization in general, but most studies do not distinguish between regulated and unregulated industries and hence are of little relevance here. ${ }^{4}$ Moreover, assessments to date generally have failed to systematically address the relevance of the many dimensions

\footnotetext{
${ }^{2}$ These models imply two major assumptions. First, they assume that it is easier for corrupt politicians to control public firms than private firms. Second, they assume that reforms make political interference costlier or at least more visible.

${ }^{3}$ For a recent review of the impact of reforms, see Kessides (2004).

${ }^{4}$ See Chong and Lopez-de-Silanes (2004) or Bortolotti and Siniscalco (2004), for instance.
} 
of performance. ${ }^{5}$ Finally, with a few exceptions discussed later, the literature has not accounted for the relevance of corruption as a driver of success of reform.

This paper addresses some of the main gaps in the current literature and makes four main contributions. First, we compare the impact of reforms across sectors, because there is no reason to expect that all sectors should adjust in the same way to reforms. The sectors we treat are electricity, fixed telecommunications, and water services delivery. While our data do not reflect all forms of supply relevant to each sector, they cover a representative share of the total population of the developing world and of the services used. $^{6}$

Second, we take into account the various dimensions of performance. ${ }^{7}$ Within each sector, we examine the impact of reforms on access, affordability, and quality of services. These dimensions correspond to the common trilogy found in textbook discussions of the regulation of monopolies-quantity, price, and quality together determine monopolistic profits and hence rents. Using all three dimensions allows us to check whether reforms in electricity and telecommunications revealed trade-offs or winwin situations across performance dimensions. We were not able to do this for water because we could not find good data on prices and quality in the water sector. Our crosssectoral, cross-dimensional assessment using a similar approach for each sector makes possible a comparative assessment of operators' preferences as revealed by the trade-offs they make among quantity, quality, and prices across sectors. Again, this contribution is limited to telecoms and electricity because of data gaps in the water sector.

Third, the largest dataset used for our analysis has the widest country coverage for the three sectors and one of the longest time spans since reforms began to be implemented (five years on average). We widened coverage on the policy side by simplifying the modeling of the reforms. Basically the extent of reforms is modeled as a binary variable: (i) either countries have managed to attract large-scale private providers or they have not; (ii) either countries have created a separate regulatory agency to supervise the sector or they have not. This simplicity has its drawbacks, as discussed later. But the benefit of being able to cover 153 developing countries for the period 19902002 should not be underestimated, even if the resulting data panels are unbalanced.

Last, but certainly not least, we provide a systematic assessment of the interactions between reform and corruption in terms of the three dimensions of performance (access, quality, and price). This may be one of the most interesting contributions to the assessment of the impact of reform. Privatization and greater autonomy of regulation are standard recommendations for fighting corruption in the theoretical literature, but most of the empirical evidence behind those recommendations is derived from the telecommunications sector and focuses on access.

\footnotetext{
${ }^{5}$ Notable exceptions focusing on utilities include Andres, Foster, and Guasch (2006), Kirkpatrick et al. (2006), Estache and Rossi (2005), Ros (1999) and Wallsten (2001, 2003), but these papers all focus either on a specific sector, a specific region, or the interaction between competition and privatization.

${ }^{6}$ In developing countries, there are alternatives to electricity as a source of energy, and mobile phones are a very good substitute for fixed lines for a very large share of the population.

7 The forthcoming book by Andres, Foster, and Guasch (2006) works with eight performance criteria across utilities. Their work is at the firm level, however, and focuses on Latin America exclusively.
} 
Our analytical approach may be summarized as follows. We first analyze what the basic data reveal. We do so to expose the shortcomings of the basic data analysis often reported in popular publications in articles on performance changes associated with changes in ownership, market structure, and regulation. Our basic correlation analysis suggests that reform policies have improved infrastructure performance in terms of access, affordability, and quality. We then test the robustness of these conclusions econometrically, revealing several forms of misinformation to which the basic data analysis can lead. For each output, we conduct generalized least squares estimations with country fixed effects.

The paper is organized as follows: section 2 provides a brief overview of the spread of reforms across sectors in the developing world. Section 3 explains the analytical approach adopted to analyze the impact of those reforms. Sections 4 through 6 analyze the impact of reforms on access rates, affordability, and quality, respectively. Section 7 discusses the consistency of the evidence across performance indicators for each sector. Section 8 offers concluding comments based on a brief overview of the main lessons offered by our cross-sectoral comparison.

\section{Reforms in infrastructure utilities}

For any reform, experts will argue that the devil is in the details. This is why, ideally, we should have been able to report a detailed description of the reforms carried out in each and what they were intended to achieve. Details are difficult to accommodate in cross-country comparative studies, where some broader characterization is needed. Over the last 15 years or so, the main experiments in utility reform have taken three broad forms that together have brought major changes in the role of the public sector in the delivery of infrastructure services around the world.

The first is the unbundling of the regulatory function. Institutionally, the reform implies the establishment of "independent regulatory agencies" (IRAs). ${ }^{8}$ The major outcome expected from this step is a switch from self-regulated or politically regulated providers of services to providers, public or private, that are monitored and controlled by agencies without interference from the elected government and without the conflicts of interest that self-regulation implies.

The theory has been easier to spell out than the practice. Depending on the sector, the country, and the institutional context, the degree of independence and the extent of the responsibilities of IRAs vary significantly. ${ }^{9}$ This diversity is difficult to capture properly. We lack data on the characteristics of regulatory agencies around the world. On the other hand, it is possible to collect data on which countries have created IRAs, and

\footnotetext{
${ }^{8}$ Throughout the data collection process we worked with the definition of independence given by the International Telecommunications Union (ITU) for telecoms and tried to apply it across sectors. ITU considers that an IRA is independent if it is separate from the ministry and from the incumbent operator in terms of its financing, structure, and decision making.

${ }^{9}$ As pointed out by Wallsten (2003), subjectivity affects the methods used to collect and report data. Wallsten states that regulators may have incentives to report that they are independent even if they are not. He also argues that no matter the definition of independence, regulatory agencies always will be to some degree connected to the government. Brown and others (2006) offer a checklist of the relevant characteristics of regulation at a very detailed level, as well as a useful survey of the literature on the topic.
} 
when, to regulate which sectors, at least nominally, and to make cross-country comparisons using those data. The establishment of an IRA is often taken as a strong signal of the government's commitment to end self-regulation and to replace political considerations by economic concerns. ${ }^{10}$ It is rarely that simple, however, as we shall see.

The second and third most common infrastructure reforms of the last 15 years-a wider role for the private sector and the opening of infrastructure markets to competition-are highly correlated. Technological progress and better management know-how made the introduction or increase of competition in a sector and the associated opening to the private sector serious options in sectors that had been dominated by national public monopolies. As a result, many reform programs separated state-owned giants into several smaller companies. These were then sold, bid out as concessions, or licensed to private operators, which were expected to compete with the incumbents and other entrants.

Because there is no reliable measure of the degree of competition in a large sample of countries over a long period of time, the existence of private participation may well be the best proxy for the commitment of a government to increase competition in a given sector. The proxy requires very little information and yet gives a reasonable sense of a government's willingness to open the economy. Moreover, it does so for the largest possible sample of countries and in a way that is comparable across sectors. Clearly it is not a perfect indicator. ${ }^{11}$ Opening to the private sector is necessary but not sufficient to increase effective competition. But for countries for which more detailed information is available for both variables, the correlation between private participation and the more detailed information is extremely high. The main apparent exception is the water sector, where the presence of the private sector is associated with ex-ante competition (that is, competition for the market) and very little ex-post competition (competition in the market among several providers). ${ }^{12}$

As in the case of independent regulation, the definition of private participation is a challenge. There are indeed many possible definitions. ${ }^{13}$ The definition of private participation in infrastructure (PPI) used here varies according to the sector to reflect differences in technology and market structure across sectors. In electricity, we focus on

\footnotetext{
${ }^{10}$ Initially, most monopolistic state-owned utilities were self-regulated or government regulated. Thus, regulation was not service-oriented, but rather related to fiscal or employment concerns. Tariffs were designed to generate fiscal revenues rather than to reflect costs and cross-subsidy schemes.

${ }^{11}$ In telecoms, PPI in fixed lines probably gives a lower bound of the extent to which competition prevails. Indeed, in Africa, for instance, even if about $50 \%$ of the fixed lines are still operated publicly, all providers, including the public ones, are subject to competition from mobile providers. In energy and in water, in many countries, the large scale private sector picked up by our PPI variables is also subject to competition from local small and medium scale providers around the world as discussed in Kariuki and Schwartz (2005).

${ }^{12}$ The data on competition raise other issues. For example, international databases on the existence of competition often refer to the "legal" status but not to the "de facto" situation.

13 Budds and McGranahan (2003) present a very useful classification of private participation in terms of the responsibilities of the private parties, which helps to make the definition less arbitrary. They argue that different degrees of private participation can be identified by assessing the involvement of private parties in asset ownership, capital investment, commercial risk, and/or operations and maintenance. Today, there is no database on the market that reports this kind of detail for any country, for any sector.
} 
distribution, because, in most countries, that is generally where rents are either captured by the operator or shared with users. More specifically, we measured PPI in the sector by the year private parties started to participate in asset ownership, capital investment, commercial risk, and/or operation and maintenance in electricity distribution.

For telecoms, we rely on the definition used by the International Telecommunications Union (ITU). According to ITU, PPI refers to full or partial private ownership of the assets of fixed-line telephone companies. We focus on fixed-line telephony because in most countries the private sector is active in mobile telephony. This is equivalent to having PPI in all countries, which would be much less interesting as an econometric variable. The degree of PPI in fixed telephone companies is an indication of the extent to which the public sector has been willing or able to rely on private financing for the expansion of fixed-line services. In Africa, for instance, PPI is found in fixed telephony in just 50 percent of countries. In water, PPI refers to asset ownership or capital investment. It ignores management contracts, which involve private management rather than capital.

With these definitions and issues in mind, we began to collect data from various sources, relying on a Web search and commercial databases to get a first impression of the situation. For telecoms, the information was relatively easy to collect, thanks to the ITU database. For water and for electricity, however, the information was partial and sometimes inconsistent across sources. We then prepared a questionnaire which we sent to colleagues in international organizations directly involved in the reforms of these sectors across the developing world. Their responses helped us to reduce the inconsistencies. When necessary, we contacted the relevant country authorities to settle uncertainties or disagreements across sources. The data samples vary across sectors because, in spite of our consultations with the key actors, we were not able to obtain for electricity and water the same coverage that ITU has managed to generate for telecoms. Our country coverage ranges from 120 to 153, depending on the indicator and the sector. This is still quite a significant advance over prior publications in electricity and water. ${ }^{14}$

The information we collected on the spread of IRAs and PPI between 1990 and 2004 is summarized in Table 1. The baseline (1990) reveals a distinct preference around the world for self-regulated public provision. Since then, the share of countries with an IRA and PPI has swelled in all sectors. But some sectors have seen their ownership and institutional structure change much more than others.

Table 1 also reports the information we collected on the timing of the reforms in the three sectors covered. On average the reforms began at roughly the same for the three sectors. The average start was around 1998, with the water sector lagging by a year. Contrary to what is viewed today as best practice, most countries established their IRA shortly after opening their telecoms and water sectors to private participation. Our data panel covers, on average, about five years of experience with reform. For some countries, of course, the coverage is much longer. Argentina, for example, commenced reforms in all three sectors between 1991 and 1993.

\footnotetext{
${ }^{14}$ For more details about the data-gathering process see Estache and Goicoechea (2005).
} 
Table 1 Worldwide spread of infrastructure reforms, 1990-2004

\begin{tabular}{|c|c|c|c|}
\hline & (number 0 & $\begin{array}{l}\text { ntage of } \mathrm{S} \\
\text { tries cover }\end{array}$ & sample) \\
\hline & Electricity & Telecoms & Water \\
\hline Countries with IRA in 1990 & $\begin{array}{c}4 \\
(141)\end{array}$ & $\begin{array}{c}5 \\
(153)\end{array}$ & $\begin{array}{c}1 \\
(115)\end{array}$ \\
\hline Countries with IRA in 2004 & $\begin{array}{c}54 \\
(134)\end{array}$ & $\begin{array}{c}67 \\
(153)\end{array}$ & $\begin{array}{c}23 \\
(120)\end{array}$ \\
\hline Average year of establishment of IRA* & 1998 & 1998 & 1999 \\
\hline Countries with PPI in 1990 & $\begin{array}{c}4 \\
(135)\end{array}$ & $\begin{array}{c}9 \\
(129)\end{array}$ & $\begin{array}{c}3 \\
(125)\end{array}$ \\
\hline Countries with PPI in 2004 & $\begin{array}{c}37 \\
(136)\end{array}$ & $\begin{array}{c}60 \\
(144)\end{array}$ & $\begin{array}{c}36 \\
(125)\end{array}$ \\
\hline Average year of privatization* & 1998 & 1997 & 1998 \\
\hline
\end{tabular}

Source: Authors' calculations.

* Average among countries that reformed between 1991 and 2004.

IRA = independent regulatory authority; PPI = private participation in infrastructure.

Note: Private participation in electricity refers to private participation in distribution.

The most reformed sector is telecoms. By 2004, 60 percent of developing countries had opened fixed telephony to the private sector. The regulatory change in the sector is even larger. The number of countries with an IRA had reached 67 percent by 2004. For electricity distribution and water, the share of countries with private participation is roughly one in three (one in two for electricity generation). There is, however, a significant difference in terms of the commitment to institutional reforms. According to Estache and Goicoechea (2004), only two-thirds of the countries that had private sector participation in their water sector had adopted an independent regulator, so that just 23 percent of countries had both. In electricity, the number of countries that had an IRA was only slightly greater than the number of those that had opened to the private sector, with the result that about 54 percent of the countries had both. This suggests that a country need not establish an IRA to get the private sector to enter the sector if other characteristics of the market are positive enough; and that establishing an IRA is not a sufficient reform to attract PPI if the market is not attractive.

\section{Methodology}

The analysis of the impact of reforms on access, affordability, and quality (the three dimensions of performance) relies on the econometric estimation of a simple model for each sector. The approach is also designed to allow a formal test of the impact on performance of the interactions between reforms and corruption. It is based on the idea that performance depends on the policies that were implemented by a particular country, its governance structure, income level, population size, technological progress, and the interaction among some of these factors. Formally, the model can be expressed as:

$$
\text { (1) } Y_{i t}=\beta_{0}+P O L_{i t}{ }^{\prime} \beta_{1}+\beta_{2} C O R R_{i t}+\left(P O L_{i t}{ }^{*}{ }^{*} C O R R_{i t}\right) \beta_{3}+X_{i t}{ }^{\prime} \beta_{4}+d(t)+d_{i}+u_{i t}
$$


where $\mathrm{i}$ indexes a country, and $\mathrm{t}$ time. $\mathrm{Y}$ is a performance output reflecting access, affordability, or quality. $P O L$ is a vector of reform policies, CORR a measure of corruption, and $\mathrm{X}$ a vector of additional regressors. The term $\mathrm{d}(\mathrm{t})$ represents a linear time trend, which takes into account technological advances, and $\mathrm{d}_{\mathrm{i}}$ represents country fixed effects. For each performance output, we estimate the model with generalized least squares (GLS), using the average population of the country as analytical weights. The model is estimated for the 1990-2002 period. ${ }^{15}$ Equation (1) is run for each performance indicator and each country.

For the reform policies vector, $P O L$, we rely on the two reform variables discussed earlier. The first, IRA, reflects whether country i at time t has established an "independent" regulatory agency. The second, PRIV, reflects whether the country has opened its doors to private participation. We also model the interactions between the two variables: $\left(P O L_{i t}{ }^{\prime}=\left[I R A_{i t} P R I V_{i t} I R A_{i t}{ }^{*} P R I V_{i t}\right]\right)$.

Focusing on these two policies alone might lead one to ignore the fact that reforms do not take place in a vacuum. That would be a mistake, because there are wide differences in governance across countries that may influence the effects of reforms on performance. Governance can be included in the analysis in several ways. For example, in electricity, Zhang and others (2005) include an index of economic freedom as a determinant of electricity performance; in telecoms, Wallsten (2001) includes expropriation risk as a determinant of telecoms performance. Our sense is that among all existent governance measures, corruption may be the most appropriate to relate to infrastructure performance, even if it has been rarely used in empirical studies of sector performance. ${ }^{16}$ In our context, the level of corruption may determine the scope of action of an IRA. An IRA may perform certain functions in a highly corrupted country and very different ones in a country with very little corruption. Similarly, the level of corruption may determine the extent to which private participation is attracted to a country.

In the empirical academic literature, there are many studies about the effects of corruption on economic growth ${ }^{17}$ and about the determinants of corruption. ${ }^{18}$ However, the coverage of the impact of corruption on specific performance outputs is much more limited. We found four working papers analyzing the effects of corruption on infrastructure sectors. Estache and Kouassi (2002) show that corruption increases the cost of providing water in Africa. That result is confirmed by Kirkpatrick and others (2006), who use a larger and more recent database. Dal Bo and Rossi (2006) show that labor productivity in electricity distribution companies is hurt by corruption. However, none of these three studies explicitly accounts for the interaction between reform policies and corruption as we propose to do. The fourth study, by Guasch and Straub (2005), includes such an interaction, but the authors examine corruption's effects on the renegotiation of infrastructure concessions in Latin America, as opposed to its effects on infrastructure

\footnotetext{
${ }^{15}$ We could not cover the entire period from 1990 to 2004, because most of the relevant performance indicators are not yet available for the last two years of the period.

${ }^{16}$ The exceptions are papers on investment flows to the sector, typically flows of foreign direct investment (FDI). For a recent paper that includes all relevant references on corruption and FDI, see Ghosh Banerjee and others (2006)

${ }^{17}$ See for example Rock and Bonnett (2004), Pellegrini and Gerlagh (2004), and Méndez and Sepúlveda (2006).

${ }^{18}$ Examples are Clarke and Xu (2002) and Laffont and N'Guessan (1999).
} 
outputs. They find that the stronger the level of corruption, the more important the effect of having a regulator in place to oversee renegotiations.

Measuring the impact of corruption on performance and the interaction between corruption and reform policies allows us to test the extent to which reform policies have managed to reinforce or offset the impact of corruption and, vice versa, the extent to which corruption reinforces or offsets the impact of the policies. This is the rationale for introducing the interaction between the CORR and $P O L$ variables in the regression. However, caution is needed when drawing conclusions from the coefficients associated with these interactions. It is also important to account for other economic dimensions likely to drive infrastructure performance which could influence our inference on corruption if we failed to take them into account. Countries with poorer governance generally have lower income, and poor governance cannot be simply attributed to the effects of income. The two most obvious, as recognized in most of the literature, are incomes levels and the degree of urbanization to capture the ability to pay and the size of the market on the demand side. This is why we introduce in vector $X$, the GDP per capita in 2000 constant U.S. dollars and the urbanization rate, which captures the size of the market from the demand side.

The measure of corruption used here is a corruption index published by the International Country Risk Guide. The index offers comparable figures for about 100 developing countries over a reasonably long period of time. Defined as an assessment of corruption within the political system, the index includes financial corruption (such as bribes connected with trade, taxes, or protection), but it concentrates on corruption in the form of excessive patronage, nepotism, job reservations, "favor-for-favors," secret party funding, and suspiciously close ties between politics and business. According to the ICRG measure, average corruption levels increased 29 percent in developing countries between 1990 and 2005 (Table 2). Given the empirical evidence about the important role of corruption for economic outcomes, the observed increase in the corruption index may be an important determinant of outputs in infrastructure sectors.

Table 2 Evolution of average corruption between 1990 and 2004

\begin{tabular}{|lccc|}
\hline & Average & $\begin{array}{c}\text { Standard } \\
\text { deviation }\end{array}$ & $\begin{array}{c}\text { Number of } \\
\text { observations }\end{array}$ \\
\hline Corruption index (0=low 1=high) & & & \\
\hline 1990 & 0.52 & 0.19 & 93 \\
\hline 1995 & 0.49 & 0.16 & 94 \\
\hline 2000 & 0.57 & 0.16 & 104 \\
\hline 2005 & 0.67 & 0.11 & 104 \\
\hline Source: Authors' calculations using data from ICRG. & & & \\
\hline
\end{tabular}

From a more technical viewpoint, it may be worth mentioning that our model assumes that the adoption of a certain reform policy is conditionally exogenous to the error term in the model. Because we control for country fixed effects, a linear trend, and GDP per capita, we completely absorb differences in the outcome variables due to intrinsic characteristics of each country that do not vary over time (their history, for example), changes in economic performance, and the generalized trend in IRA and 
privatization. Ultimately, we are arguing that, conditional on these covariates, policy reforms are not correlated to the error term and that GLS estimates of the coefficients on the policy variables are consistent. We based this hypothesis on the fact that in most developing countries reforms were initially implemented to improve fiscal deficits and not to improve performance. This may be seen as a limitation of the paper, but the alternative was to depend on unreliable instruments. We chose to avoid such reliance, because there is no theoretically convincing argument demonstrating that bad instruments will yield better results than the assumption we are making here.

The coverage of our data is extensive, but there is a great deal of variability across sectors and variables. For each dependent variable, we used the largest possible sample and, to reduce sample selection biases, included countries that have reformed as well as countries that have not reformed. We constructed one data panel for each sector. For electricity and telecoms, the unbalanced panels each contain 1,989 observations, including data for 153 developing countries during the period 1990-2002. For these sectors we were able to assess performance in terms of access, affordability, and quality. However, our water coverage is much more limited. We were able to collect data only for access and for two time periods. Thus, the unbalanced water panel contains 306 observations, including data for 153 developing countries for 1990 and 2002. Because of the size of the water panel, we did not include country fixed effects in these regressions.

A final comment deals with the way the econometric results need to be read. It is essential not to take each coefficient at face value. Regression coefficients represent the effects of policies under specific scenarios, and not the total average effect of policies across countries. For example, in equation (1), the coefficient of the dummy variable that reports whether or not a country has an IRA expresses the effect of an IRA on performance only in those countries that do not have private participation and in which the corruption index is equal to zero. The marginal effect, by contrast, considers all the information jointly and provides the correct assessment of the average impact of reform policies and corruption on performance across countries.

To compute the marginal effects of the IRA variable, the first-order derivative of equation (1) with respect to IRA needs to be computed. Next, all the variables in the derivative need to be set to their average value. This is done by taking the data sample used for the regression and then computing the average (or the share of the sample, according to what the derivative requires). Finally, the hypothesis that the derivative is equal to zero needs to be tested with a t-test. We repeat this procedure to get the marginal effects of privatization and of corruption.

Note that the need to calculate the marginal effect does not imply that the econometric model itself is unimportant for drawing policy conclusions. Indeed, it provides an opportunity to test the statistical significance of bilateral interactions, such as independent regulation with privatization, corruption with privatization, and corruption with independent regulation. 


\section{Impact of reforms on access rates}

This section focuses on the impact of reform on the first measure of utility performance: access. We first explain how and why we picked our specific performance proxies. We then move to a basic data analysis in which we describe their evolution between 1990 and 2002, distinguishing between groups of countries that have reformed and those which have not. This serves as a benchmark for a discussion of the extent to which the econometric analysis can provide additional insights.

\subsection{Selection of access indicators}

There is disagreement in the literature on how to define access. Should it be a measure of the extent to which people have the right to obtain, use. or take advantage of infrastructure services? Or, should it be a measure of the actual consumption by users? There is no consistent approach across the three sectors.

In electricity, for now, the only information on access rates defined as an entitlement and available for a large number of countries is a survey conducted in 2002 by the International Energy Agency (IEA) that reports access for the year 2000. However, that information is not enough to estimate the panel data required by the econometric model. An alternative is thus needed. Generation capacity is often used as a proxy for access (Cubbin and Stern 2001; Zhang and others 2002 and 2005). We prefer to use levels of energy use per capita (expressed in $\mathrm{kg}$ of oil equivalent), defined by the IEA as "apparent consumption, which is equal to indigenous production plus imports and stock changes, minus exports and fuels supplied to ships and aircraft engaged in international transport.” The IEA measure yields a much larger dataset—but it has a cost. In the energy sector, any change in consumption, in particular in higher-income countries, may result from demand-management policies designed to reduce usage. In our context, such a reduction would be interpreted as a reduction in access, which would distort the real story.

In telecoms, there are multiple access indicators with time series available. The number of mainlines (see definition, below) is one of the most popular choices, sometimes accompanied by an indicator of mobile penetration. ${ }^{19}$ We chose the number of telephone subscribers per 1,000 people, because it includes both fixed mainlines and mobile subscribers, better representing the market options available today. ITU defines this measure as the number of fixed lines plus the number of mobile subscribers per 1,000 people, where fixed lines are "telephone mainlines connecting a customer's equipment to the public switched telephone network," while "mobile phone subscribers refers to users of portable telephones subscribing to an automatic public mobile telephone service using cellular technology that provides access to the public switched telephone network." This indicator may over- or underestimate access because, as Wallsten (2001) explains, it is not possible to differentiate if one person has multiple lines, or if one line is used by multiple persons.

To measure access in the water sector, we use the percentage of population with access to improved water sources published by the Joint Monitoring Program (JMP), the

\footnotetext{
${ }^{19}$ Examples can be found in Ross (1999), Wallsten (2001 and 2003), Fink and others (2001 and 2002), Gutiérrez (2003), and Li and Xu (2004).
} 
only water access indicator available for a reasonably large sample of countries. JMP defines access as follows:

“[t]he availability of at least 20 liters of improved water per person per day from a source within one kilometer of the user's dwelling. Improved water supply sources are: household connection, public standpipe, borehole, protected dug well, protected spring, rainwater collection. Unimproved sources include unprotected well, unprotected spring, vendor-provided water, bottled water (based on concerns about the quantity of supplied water, not concerns over the water quality), and tanker truck-provided water."

Our choice was based solely on data availability and not on the quality of the indicator. Other indicators, although better, have serious coverage issues. For example, Clarke, Kosec, and Wallsten (2004) were able to gather household data on the number of connections to piped water, but only for some Latin American countries. They noted how difficult it is to find cross-country data in the water sector. In theory, access to improved water sources as defined by JMP is a good indicator of access, because it is based on household data and is available for multiple countries, but it is available only for two points in time. Furthermore, the JMP estimates access values by running a regression with data from multiple household surveys and using the estimated coefficients to calculate access in 1990 and 2002. The access figures for these two time periods are constantly reestimated as more surveys are carried out. Thus, it is difficult to track the marginal improvements in access to water over time.

\subsection{Basic data analysis}

On average, access has improved in all sectors between 1990 and 2002 (Table 3). The greatest improvement is observed in the telecoms sector (an increase of 330 percent), followed by electricity (22 percent), and water ( 7 percent). This difference reflects both technological advances and changes in the sectors. The fact that there has been very little technological progress in energy and water, however, suggests that the other factors may be relatively more important-in particular, the potential contribution of reform policies. Technology is no doubt the driving force in the telecoms sector.

Table 3 Evolution of average access between 1990 and 2002

\begin{tabular}{|lccc|}
\hline & Average & $\begin{array}{c}\text { Standard } \\
\text { deviation }\end{array}$ & $\begin{array}{c}\text { Number of } \\
\text { observations }\end{array}$ \\
\hline Energy use (kg of oil equivalent per capita) & & & \\
\hline 1990 & 1098 & 1071 & 76 \\
\hline 2002 & 1335 & 1255 & 95 \\
\hline Telephone subscribers per 1,000 people & & & \\
\hline 1990 & 57 & 70 & 150 \\
\hline 2002 & 245 & 269 & 151 \\
\hline $\begin{array}{l}\text { Access to improved water sources (percentage of } \\
\text { population) }\end{array}$ & & & \\
\hline 1990 & 72 & 21 & 102 \\
\hline 2002 & 77 & 19 & 138 \\
\hline
\end{tabular}

Source: Authors' calculations using data from WDI, JMP, WHO, and UNICEF. 
To relate access indicators to reform policies, we calculated averages for different groups of countries according to the status of their reform implementation. In all sectors, countries that established an IRA and introduced private participation have higher average access than countries that did not implement either of these policies (Table 4, columns 1 and 4). We can also look at the average access of countries that decided to implement only one of these policies (columns 2 and 3). In electricity, establishing an IRA seems to be more important than introducing private participation when it comes to access. The opposite is observed in telecoms; countries with an IRA have lower access than those with private participation. In water, there seems to be no difference. Overall, ignoring the fact that each group may reflect a selection bias, the story that emerges is that reforms helped the access performance across sectors.

Table 4 Access vs. reform policies in 2002

\begin{tabular}{|c|c|c|c|c|c|}
\hline & & andard deviat & $\begin{array}{l}\text { Average } \\
n \text {; number of }\end{array}$ & bservations) & \\
\hline & 1 & 2 & 3 & 4 & 5 \\
\hline & $\begin{array}{l}\text { Without IRA } \\
\text { Without PPI }\end{array}$ & $\begin{array}{c}\text { With IRA } \\
\text { Without PPI }\end{array}$ & $\begin{array}{l}\text { Without IRA } \\
\text { With PPI }\end{array}$ & $\begin{array}{l}\text { With IRA } \\
\text { With PPI }\end{array}$ & $\begin{array}{c}\text { All } \\
\text { countries }\end{array}$ \\
\hline $\begin{array}{l}\text { Energy use (kg of oil } \\
\text { equivalent per capita) }\end{array}$ & $\begin{array}{c}1,249 \\
(1,255 ; 36)\end{array}$ & $\begin{array}{c}1,769 \\
(1,511 ; 22)\end{array}$ & $\begin{array}{c}632 \\
(500 ; 3)\end{array}$ & $\begin{array}{c}1,271 \\
(1,116 ; 30)\end{array}$ & $\begin{array}{c}1,362 \\
(1,272 ; 91)\end{array}$ \\
\hline $\begin{array}{l}\text { Telephone } \\
\text { subscribers/1,000 } \\
\text { people }\end{array}$ & $\begin{array}{c}154 \\
(206 ; 26)\end{array}$ & $\begin{array}{c}161 \\
(189 ; 40)\end{array}$ & $\begin{array}{c}242 \\
(201 ; 15)\end{array}$ & $\begin{array}{c}363 \\
(347 ; 47)\end{array}$ & $\begin{array}{c}243 \\
(276 ; 128)\end{array}$ \\
\hline $\begin{array}{l}\text { Access to improved } \\
\text { water sources } \\
\text { (percent of population) }\end{array}$ & $\begin{array}{c}71 \\
(19 ; 63)\end{array}$ & $\begin{array}{c}81 \\
(13 ; 7)\end{array}$ & $\begin{array}{c}81 \\
(18 ; 22)\end{array}$ & $\begin{array}{c}77 \\
(22 ; 9)\end{array}$ & $\begin{array}{c}77 \\
(19 ; 138)\end{array}$ \\
\hline
\end{tabular}

Source: Authors' calculations using data from WDI, ITU, and WHO.

Note: For some indicators, coverage in 2002 is not as good as for previous years. Thus, for some groups samples are too small to draw significant conclusions.

IRA refers to the existence of an indenendent reaulatorv aqencv. PPI refers to the existence of private narticination.

\subsection{Econometric analysis}

The econometric results are provided in Table 5. The best model in terms of the $\mathrm{R}$-squared is the one for telecoms. The worst one is for water, even after accounting for the fact that there is a strong demand for water for irrigation (proxied by the addition of agricultural value added as an explanatory variable). The sample size for that sector is also significantly lower than for the other sectors.

The econometric results nuance the "naïve" impressions that could be drawn from Table 4. They show that the effectiveness of reforms depends on the sector and on the reform. The marginal effects reported at the bottom of the table show that the effect of corruption on access varies by sector. Of particular interest are the statistical significance and the sign of the marginal effects.

Keeping in mind that these are average effects for a wide range of countries, the initial story is sobering. Increasing PPI in telecoms had the expected effect of increasing access. However, in electricity and in water, it did not have a statistically significant effect during the period of analysis, contrary to the impression left by the basic data analysis (Table 5, line 16). 
The results for the introduction of IRAs are even more puzzling. For the period covered by our sample the presence or absence of an IRA did affect the access rate in the water sector. However, it was associated with a statistically significant reduction in access rates in electricity and in telecoms (line 15).

Finally, whatever the impact of either reform, the coefficient on their interaction (line 3) suggests that together they exert beneficial effects in electricity and telecoms but do not interact in the water sector.

Table 5 Econometric results for access, 1990-2002

\begin{tabular}{|c|c|c|c|c|}
\hline & & (1) & (2) & (3) \\
\hline & & $\begin{array}{c}\text { Ln energy use (kg of } \\
\text { oil equivalent per } \\
\text { capita) }\end{array}$ & $\begin{array}{l}\text { Ln telephone } \\
\text { subscribers/1,0 } \\
00 \text { people }\end{array}$ & $\begin{array}{l}\text { Ln access to improved } \\
\text { water sources (percent } \\
\text { of population) }\end{array}$ \\
\hline \multirow[t]{2}{*}{ (1) } & IRA & 0.016 & -0.063 & -0.425 \\
\hline & & {$[0.55]$} & {$[0.76]$} & {$[1.16]$} \\
\hline \multirow[t]{2}{*}{ (2) } & Privatization & $-0.066^{\star *}$ & 0.055 & $0.234^{* *}$ \\
\hline & & {$[2.16]$} & {$[0.79]$} & {$[1.98]$} \\
\hline \multirow[t]{2}{*}{ (3) } & IRA * privatization & $0.031^{*}$ & $0.214^{\star \star \star}$ & -0.243 \\
\hline & & [1.66] & [5.57] & [1.28] \\
\hline \multirow[t]{2}{*}{ (4) } & Corruption index & $-0.092^{\star \star \star}$ & $0.548^{\star * \star}$ & $-0.476^{\star \star \star}$ \\
\hline & (0=low 1=high) & [6.23] & {$[9.80]$} & [3.72] \\
\hline \multirow[t]{2}{*}{ (5) } & IRA * corruption & $-0.111^{\star \star}$ & $-0.290^{* *}$ & 1.156 \\
\hline & & {$[2.16]$} & {$[2.22]$} & [1.30] \\
\hline \multirow[t]{2}{*}{ (6) } & Privatization * & $0.095^{\star}$ & 0.023 & -0.416 \\
\hline & Corruption & [1.75] & {$[0.23]$} & [1.01] \\
\hline \multirow[t]{2}{*}{ (7) } & Ln GDP per capita & $0.195^{\star \star \star}$ & $1.884^{\star \star \star}$ & $0.342^{\star \star \star}$ \\
\hline & (2000 US\$) & [11.58] & {$[33.24]$} & {$[5.03]$} \\
\hline \multirow[t]{2}{*}{ (8) } & Ln Urbanization & $-0.123^{*}$ & $1.625^{\star \star \star}$ & -0.068 \\
\hline & & {$[1.92]$} & {$[8.03]$} & {$[0.75]$} \\
\hline \multirow[t]{2}{*}{ (9) } & Time trend & $0.013^{\star \star \star}$ & $0.102^{\star \star \star}$ & \\
\hline & & {$[10.25]$} & {$[24.64]$} & \\
\hline & Ln agricultural value & & & $0.191^{\star *}$ \\
\hline & & & & {$[2.50]$} \\
\hline \multirow[t]{2}{*}{ (11) } & Constant & $-19.610^{\star \star *}$ & $-222.553^{* \star *}$ & $1.571^{\star \star}$ \\
\hline & & [7.93] & [28.79] & {$[2.31]$} \\
\hline (12) & Observations & 929 & 1108 & 122 \\
\hline (13) & R-squared within & 0.64 & 0.96 & 0.54 \\
\hline (14) & No. of countries in sample & 80 & 92 & 72 \\
\hline \multicolumn{5}{|c|}{ Marginal effects } \\
\hline (15) & IRA & $\begin{array}{c}-0.035^{\star \star \star} \\
{[3.77]}\end{array}$ & $\begin{array}{c}-0.148^{\star \star \star} \\
{[5.30]}\end{array}$ & $\begin{array}{l}0.061 \\
{[0.58]}\end{array}$ \\
\hline (16) & PRIV & $\begin{array}{l}-0.007 \\
{[0.58]}\end{array}$ & $0.149^{\star \star \star}$ & $\begin{array}{l}-0.017 \\
{[0.29]}\end{array}$ \\
\hline (17) & CORRUPTION & $-0.107^{\star \star \star}$ & $0.443^{\star \star \star}$ & -0.181 \\
\hline (17) & CORRUPTION & [6.58] & [7.18] & {$[0.74]$} \\
\hline
\end{tabular}


The story emerging on the impact of corruption is also complex (line 17). In electricity, corruption is associated with a lower access rate, as expected-that is, an increase in the corruption index was associated with a decline in energy use. In the water sector, corruption does not seem to have had a statistically significant impact on access rates. The results for telecoms were unexpected: greater corruption is linked to higher access. As discussed later, these effects need to be assessed simultaneously with the two other performance dimensions to check for possible trade-offs made by operators.

How reforms have affected the interaction of corruption and access rates may be the most politically sensitive contribution of this paper (lines 5 and 6). Reforms were expected, of course, to improve utility coverage among the population. Access was to become an entitlement, no longer a "favor" bestowed by a corrupt bureaucrat. But our results suggest that reforms do not necessarily have the expected impact on corruption. The positive sign of the statistically significant interaction term between corruption and PPI means two things. It means that PPI seems to influence the effects of corruption in electricity but it also means that corruption influences the effects of PPI on access. ${ }^{20}$ The lack of statistical significance of the effects in the other sectors implies that reforms are not effective in addressing the impact of corruption on access in those sectors. More positively, it also means that corruption does not interfere with the impact of reform on access rates.

The negative sign of the statistically significant interaction term between corruption and IRA means that the presence of an IRA seems to offset the effects of corruption in electricity and in telecoms. It also means that corruption reduces the effects of the IRA on access in those sectors. The lack of statistical significance of the effects in the water sector implies that reforms have not been effective in addressing the impact of corruption on access in that sector, and that corruption does not interfere with the impact of reform on access rates.

Adding up the coefficients in rows 4 to 6 in the table yields an assessment of the joint impact of the two reforms on the effects of corruption on access. This assessment is relevant only in electricity, where all of the coefficients are statistically significant. In that case, the negative effects of corruption on access are higher in countries that have adopted the two reforms (sum of rows 4 to 6 ) than in countries that have not reformed (row 4).

\section{Impact of reforms on affordability}

This section discusses the impact of reforms on user prices, which we use to approximate the performance dimension of affordability. As in section 4, we first explain how and why we picked our proxies. We then move to a basic data analysis before discussing the econometric results.

\footnotetext{
${ }^{20}$ Note that whether the desirability of a reinforcing or mitigating effect of reform depends the sign of the direct effect of corruption on performance
} 


\subsection{Selection of affordability indicators}

Affordability indicators should give a sense of the extent to which infrastructure services are provided at a price consistent with the income levels of residential usersignoring for now the consistency of costs and prices. Ideally, affordability measures will capture the extent to which the price of a standard consumption bundle is consistent with users' ability to pay. These measures should be collected from household surveys that specify the percentage of household income or household expenditure allocated by different income classes to a specific service.

The only practical information available for a large set of countries is the average price and, occasionally, the tariff structure. This information is widely seen as problematic, however, because it does not account for the informal alternatives available to consumers in developing countries. But because it is the only information available for a large sample of countries, it is used in the few econometric studies of reforms. For example, Steiner (2001), Zhang and others (2002 and 2005), and Hattori and Tsutsui (2004), use electricity end-user prices as an independent variable to study the impact of reforms. For telecoms, three cross-country studies document the impact of reforms on prices (Boylaud and Nicoletti 2000; Ross 2001 and 2003).

We chose electricity end-user prices for households and for industry as proxies for affordability. End-user prices are defined as prices actually paid, net of rebates, including nonrefundable taxes and transport costs that the consumer must pay as part of the transaction, but excluding value-added tax. Data were collected from the following sources: IEA, Energy Regulators Regional Association (ERRA), Energy-Economic Information System of Latin America and the Caribbean (SIEE-OLADE), and South African Development through Electricity (SAD-ELEC). The chief limitation of data on electricity prices is coverage. We were able to get prices for just 56 of 153 developing countries.

To proxy the affordability of telecom services, we relied on the price for a threeminute local phone call in U.S. cents and the monthly subscription fee in U.S. dollars (for residents and for business). ITU defines the price of local calls as "the cost of a peak rate 3-minute fixed line call within the same exchange area using the subscriber's own terminal." The monthly residential (or business) phone subscription fee is defined as "the recurring fixed charge for a residential (business) subscriber to the public switched telephone network.” The charge covers the rental of the line but not the rental of the telephone set where the equipment market is liberalized. In some cases, the rental charge includes an allowance for free or reduced-rate call units. If there are different charges for different exchange areas, the largest urban area is used. These indicators refer to prices in the fixed-line market and do not include mobile-market prices.

We could not find reliable databases at the national level in the water sector. Most data are collected at the company level, and most companies serve only a limited segment of the population. This may be why no comparable data is available at the country level. 


\subsection{Basic data analysis}

Average electricity prices for both households and industry increased between 1990 and 2002 (Table 6). The increase probably was driven by significant improvements in cost-recovery efforts introduced in a wide range of countries during the 1990s, often as a component of reforms aimed at reducing direct public subsidies. In contrast, the average price of a local telephone call, as well as average monthly residential and business subscription fees, decreased thanks to technology-driven cost reductions and tariff rebalancing, which was a common features of reforms in the 1990s. The ratios of local call costs in 2002 to the same costs in 1990, compared with the ratios of subscription fees, illustrate the effect of tariff rebalancing. Indeed, average tariffs decreased more than connection fees. The basic picture is that electricity seems to have become less affordable, while telecomunications have become more affordable.

Table 6 Evolution of average prices, 1990-2002

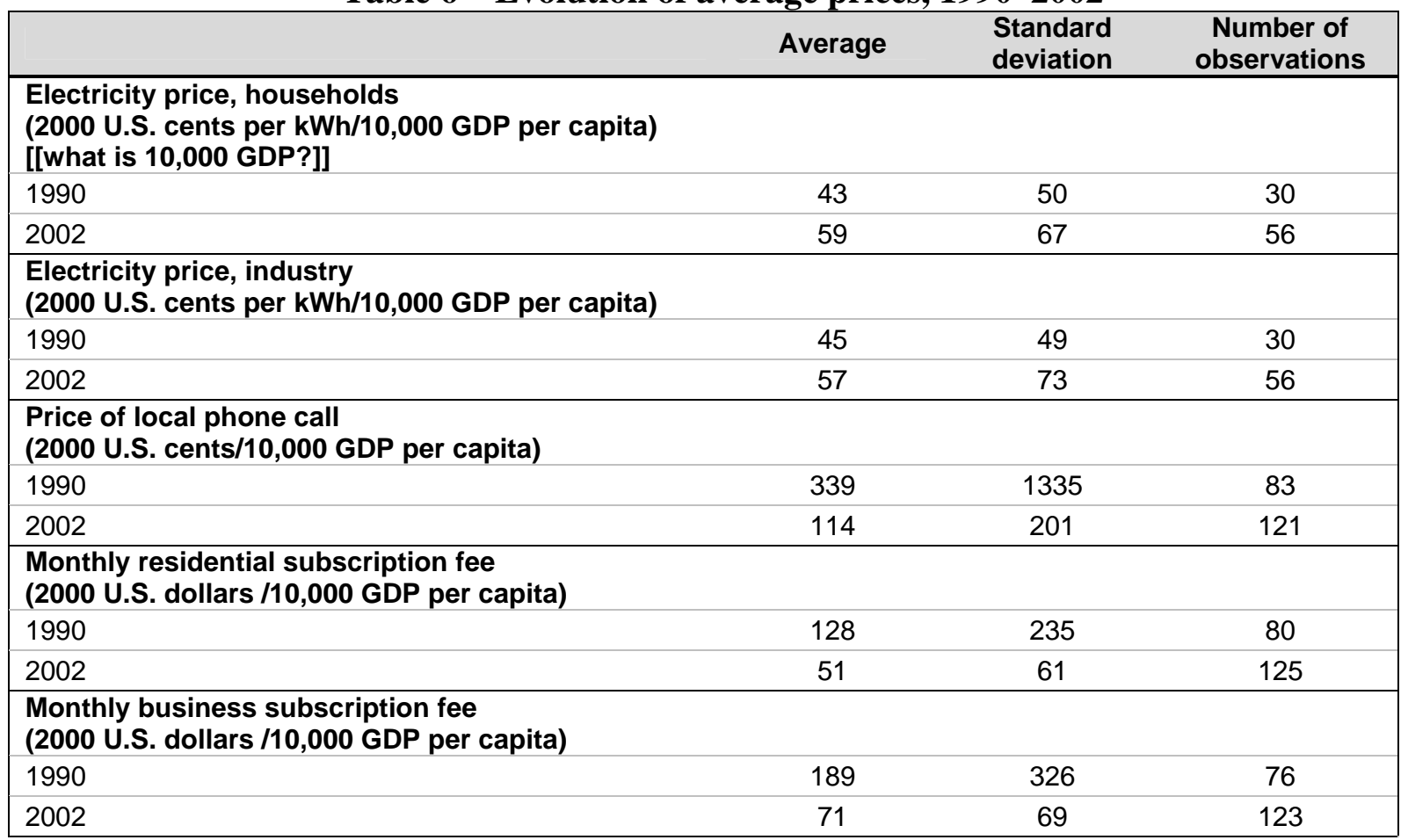

Source: Authors' calculations using data from EIA, ERRA, OLADE, and SAD-ELEC.

In order to relate affordability to out two reforms, Table 7 presents "affordability" indicators for different country groups according to the extent to which they have adopted reforms (samples for some groups are too small to permit any conclusions to be drawn). This is the typical way in which anecdotal assessments of the impact of reforms on affordability are done. It does not really tell a statistically robust story, but it is widely popular among the partisans of anecdotal evidence on the impact of “privatization". 
Table 7 Affordability vs. reform policies in 2002

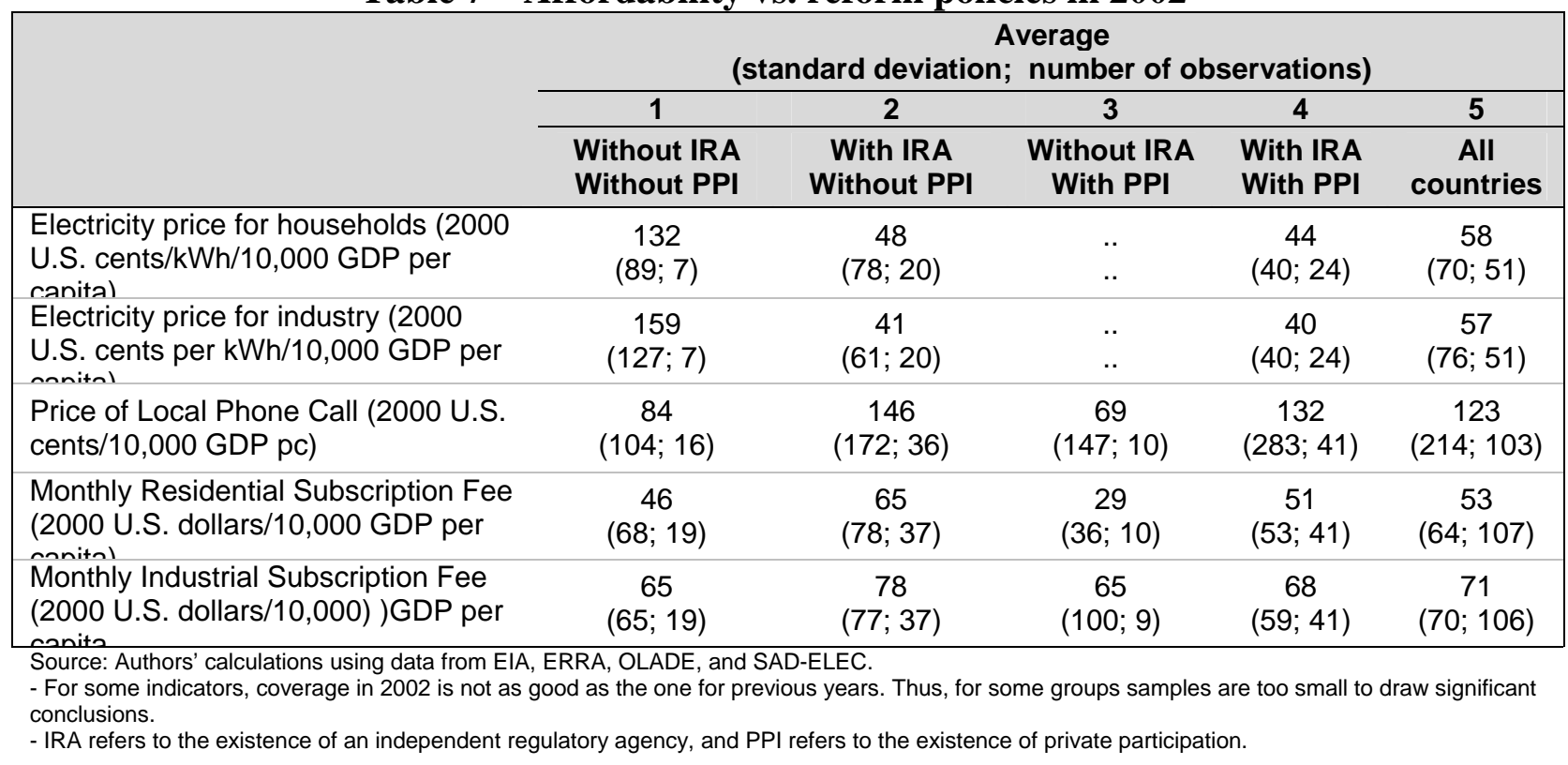

This basic data analysis implies that electricity prices are lower in reformed economies than in economies that have not adopted either of the reforms we are examining. In telecoms, countries that have not reformed have average lower local prices than countries that have reformed. This reflects improvements in cost recovery but also tariff rebalancing, on which most telecoms reforms placed heavy emphasis. With rebalancing, cross-subsidies from international calls to local calls, for example, tend to disappear. Interestingly, the basic data analysis suggests that the lowest costs for local calls are found in countries that have increased private sector participation without adopting regulatory agencies. In other words, the basic data analysis suggests that the presence of an IRA in the telecoms sector is associated with a worsening of affordability.

\subsection{Econometric analysis}

The marginal effects of reforms on affordability, computed from the econometric results, are reported in the lower part of Table 8. They confirm some of the observations from the basic data analysis. First IRAs are not equally effective across sectors or users (Table 8, line 14). Establishing an IRA in electricity was significantly associated with reduced prices for households, but not for industry. For telecoms, the presence of an IRA was associated with an increase in the average cost of a local call but had no effect on subscription fees.

PPI affected almost all of the prices we looked at (line 15). However, those effects were different from the ones suggested by the basic data analysis. In electricity, private participation was associated with an increase in end-user prices for households (negatively affecting affordability) but had no effect on industrial prices. In telecoms private participation was associated with higher residential and business monthly subscription fees but lower prices for local calls, consistent with the rebalancing policies discussed earlier. 
Corruption proved to have fewer statistically significant effects on affordability than on access during the period of analysis (line 16). One exception stands out. On average, an increase in corruption was associated with an increase in the price of a local phone call. Because it has no effects on the fixed connection cost, it is likely that the impact is on variable costs and interconnection rates.

Table 8 Econometric results for affordability, 1990-2002

\begin{tabular}{|c|c|c|c|c|c|c|}
\hline & & (1) & (2) & (3) & (4) & (5) \\
\hline & & $\begin{array}{l}\text { Ln } \\
\text { electricity } \\
\text { price for } \\
\text { households } \\
\text { (2000 U.S. } \\
\text { cents/kWh) }\end{array}$ & $\begin{array}{c}\text { Ln } \\
\text { electricity } \\
\text { price for } \\
\text { industry } \\
\text { (2000 U.S. } \\
\text { cents/kWh) }\end{array}$ & $\begin{array}{c}\text { Ln price of } \\
\text { local } \\
\text { telephone } \\
\text { call ( } 2000 \\
\text { U.S. } \\
\text { cents/3-min } \\
\text { call) }\end{array}$ & $\begin{array}{l}\text { Ln monthly } \\
\text { residential } \\
\text { subs. fee } \\
\text { (2000 U.S.\$) }\end{array}$ & $\begin{array}{l}\text { Ln monthly } \\
\text { business } \\
\text { subs. Fee } \\
\text { (2000 U.S.\$) }\end{array}$ \\
\hline (1) & IRA & $\begin{array}{c}-0.110 \\
{[0.85]}\end{array}$ & $\begin{array}{c}-0.138 \\
{[1.21]}\end{array}$ & $\begin{array}{l}0.064 \\
{[0.38]}\end{array}$ & $\begin{array}{c}0.479^{\star \star} \\
{[2.54]}\end{array}$ & $\begin{array}{l}0.177 \\
{[0.95]}\end{array}$ \\
\hline$(2)$ & Privatization & $\begin{array}{c}0.437^{\star * *} \\
{[3.35]}\end{array}$ & $\begin{array}{c}0.310^{* * *} \\
{[2.68]}\end{array}$ & $\begin{array}{c}0.738^{\star * *} \\
{[5.16]}\end{array}$ & $\begin{array}{c}0.505^{\star * \star *} \\
{[3.08]}\end{array}$ & $\begin{array}{c}0.465^{\star * \star *} \\
{[2.91]}\end{array}$ \\
\hline (3) & $\begin{array}{l}\text { IRA * } \\
\text { Privatization }\end{array}$ & $\begin{array}{c}-0.001 \\
{[0.01]} \\
\end{array}$ & $\begin{array}{c}-0.147^{\star \star} \\
{[2.30]}\end{array}$ & $\begin{array}{c}-0.178^{\star *} \\
{[2.37]} \\
\end{array}$ & $\begin{array}{c}-0.101 \\
{[1.18]} \\
\end{array}$ & $\begin{array}{c}-0.068 \\
{[0.82]} \\
\end{array}$ \\
\hline (4) & $\begin{array}{l}\text { Corruption index } \\
(0=\text { low } 1=\text { high })\end{array}$ & $\begin{array}{c}-0.159 \\
{[0.69]}\end{array}$ & $\begin{array}{l}0.035 \\
{[0.17]}\end{array}$ & $\begin{array}{c}0.756^{\star \star \star} \\
{[4.43]}\end{array}$ & $\begin{array}{l}0.356^{*} \\
{[1.81]}\end{array}$ & $\begin{array}{l}0.217 \\
{[1.13]}\end{array}$ \\
\hline (5) & IRA * corruption & $\begin{array}{l}0.033 \\
{[0.13]}\end{array}$ & $\begin{array}{l}0.365^{*} \\
{[1.67]}\end{array}$ & $\begin{array}{l}0.341 \\
{[1.29]}\end{array}$ & $\begin{array}{c}-0.644^{* *} \\
{[2.12]}\end{array}$ & $\begin{array}{c}-0.162 \\
{[0.54]}\end{array}$ \\
\hline (6) & $\begin{array}{l}\text { Privatization * } \\
\text { corruption }\end{array}$ & $\begin{array}{c}-0.103 \\
{[0.38]}\end{array}$ & $\begin{array}{c}-0.345 \\
{[1.45]}\end{array}$ & $\begin{array}{c}-1.583^{\star * *} \\
{[6.74]}\end{array}$ & $\begin{array}{c}-0.358 \\
{[1.47]}\end{array}$ & $\begin{array}{c}-0.402^{*} \\
{[1.68]}\end{array}$ \\
\hline (7) & $\begin{array}{l}\text { Ln GDP per capita } \\
\text { (2000 U.S.\$) }\end{array}$ & $\begin{array}{c}0.636^{\star \star \star} \\
{[2.68]}\end{array}$ & $\begin{array}{c}1.305^{\star \star *} \\
{[6.19]}\end{array}$ & $\begin{array}{c}-0.454^{\star \star} \\
{[2.28]}\end{array}$ & $\begin{array}{c}-0.816^{\star \star *} \\
{[3.93]}\end{array}$ & $\begin{array}{c}-0.441^{\star *} \\
{[2.17]}\end{array}$ \\
\hline (8) & Ln urbanization & $\begin{array}{l}0.264 \\
{[0.27]}\end{array}$ & $\begin{array}{c}4.303^{\star \star \star} \\
{[4.95]}\end{array}$ & $\begin{array}{l}0.154 \\
{[0.36]}\end{array}$ & $\begin{array}{c}-3.538^{\star \star \star} \\
{[7.19]}\end{array}$ & $\begin{array}{c}-1.071^{\star \star} \\
{[2.18]}\end{array}$ \\
\hline (9) & Time trend & $\begin{array}{l}0.003 \\
{[0.32]}\end{array}$ & $\begin{array}{c}-0.063^{\star \star \star} \\
{[7.38]} \\
\end{array}$ & $\begin{array}{c}-0.058^{\star \star *} \\
{[6.16]} \\
\end{array}$ & $\begin{array}{c}0.027^{\star \star} \\
{[2.46]} \\
\end{array}$ & $\begin{array}{c}-0.019^{*} \\
{[1.73]} \\
\end{array}$ \\
\hline (10) & Constant & $\begin{array}{c}-7.348 \\
{[0.37]}\end{array}$ & $\begin{array}{c}128.654^{\star \star \star} \\
{[7.24]}\end{array}$ & $\begin{array}{c}120.283^{\star \star \star} \\
{[6.83]}\end{array}$ & $\begin{array}{c}-36.570^{\star} \\
{[1.82]}\end{array}$ & $\begin{array}{c}48.241^{\star *} \\
{[2.47]}\end{array}$ \\
\hline (11) & Observations & 380 & 380 & 943 & 968 & 957 \\
\hline (12) & R-squared within & 0.33 & 0.22 & 0.34 & 0.15 & 0.09 \\
\hline (13) & $\begin{array}{l}\text { No. of countries in } \\
\text { sample }\end{array}$ & 47 & 47 & 91 & 91 & 91 \\
\hline \multicolumn{7}{|c|}{ Marginal effects } \\
\hline (14) & IRA & $\begin{array}{c}-0.094^{\star \star} \\
{[1.98]}\end{array}$ & $\begin{array}{c}-0.007 \\
{[0.18]}\end{array}$ & $\begin{array}{c}0.183^{\star \star \star} \\
{[3.45]}\end{array}$ & $\begin{array}{l}0.112 \\
{[1.79]}\end{array}$ & $\begin{array}{l}0.071 \\
{[1.16]}\end{array}$ \\
\hline (15) & PRIV & $\begin{array}{c}0.385^{\star \star \star} \\
{[7.41]}\end{array}$ & $\begin{array}{l}0.055 \\
{[1.19]}\end{array}$ & $\begin{array}{c}-0.153^{\star \star \star} \\
{[2.89]}\end{array}$ & $\begin{array}{c}0.276^{\star \star \star} \\
{[4.52]}\end{array}$ & $\begin{array}{c}0.228^{\star \star \star} \\
{[3.83]}\end{array}$ \\
\hline (16) & CORRUPTION & $\begin{array}{c}-0.176 \\
{[1.04]}\end{array}$ & $\begin{array}{l}0.125 \\
{[0.83]}\end{array}$ & $\begin{array}{c}0.394^{\star * *} \\
{[2.74]}\end{array}$ & $\begin{array}{c}-0.022 \\
{[0.13]} \\
\end{array}$ & $\begin{array}{l}0.020 \\
{[0.13]}\end{array}$ \\
\hline
\end{tabular}

Absolute value of t statistics in brackets. ${ }^{*}$ significant at 10 percent, ${ }^{* *}$ significant at 5 percent, ${ }^{* *}$ significant at 1 percent.

The interaction dummies suggest that in general IRA and PPI do not systematically interact to influence prices (line 3). This is quite surprising, because it is 
widely argued that IRAs are needed to control the pricing behavior of monopolies. Two notable exceptions to the noninteraction of the dummy variables are in the prices of local calls and of industrial electricity. In both of these cases, the interaction is negative and stronger than the direct impact of each policy. In other words, in these two cases, the evidence suggests that the regulator indeed limits the opportunistic pricing behavior of operators.

The interactions between corruption and the reform dummies are once more the most interesting of the effects. The effect of reforms on the price consequences of corruption is, in general, less significant than suggested by theory. The introduction of an IRA influences only some of the prices of concern to the industrial consumers, reinforcing the impact of corruption on average electricity prices. In telecoms, the presence of an IRA reduces the adverse impact of corruption on household connection charges (line 5). The introduction of PPI has no impact on the price effect of corruption (line 6). It does, however, offset the impact of corruption on local call prices and on industrial connection fees in telecoms. Lines 4 to 6, considered together, suggest that the two policies never combined to affect prices significantly during the period of analysis.

\section{Impact of reforms on quality}

This section focuses quality. As in sections 4 and 5, we first explain how and why we picked our proxies in each sector. We then move to a basic data analysis before discussing the econometric results.

\subsection{Selection of quality indicators}

The measurement of quality proved to be the most challenging of the three dimensions of performance. Quality may be assessed from the technical point of view or from a service perspective. The first angle is generally based on quantitative measures, often generated by engineers. The second tends to rely on qualitative measures, often based on surveys of users. Quantitative measures are less subjective, even if they are usually reported by the utilities or providers based on self-assessments. Examples include electric outages and reported phone faults. Qualitative measures often capture the perceptions of respondents. Regardless of the merits of the two types of measures, we could not find qualitative datasets with large enough coverage for our purposes.

In electricity, we rely on power transmission and distribution losses as percentages of total output as our measure of technical quality. These are defined by IEA as "losses in transmission between sources of supply and points of distribution and in the distribution to consumers, including pilferage. Shares may not sum to 100 percent because other sources of generated electricity (such as geothermal, solar, and wind) are not shown."21 Theoretically, power transmission and distribution losses are a suitable proxy for the quality of service because the higher the losses, the higher the probability

\footnotetext{
${ }^{21}$ We found only one working paper, Vagliasindi (2004), on the effects of reform policies on technical quality in electricity; it, too, used the IEA measure. The paucity of academic literature on electricity quality is in part due to data limitations.
} 
that firms have operational problems that affect the quality of service from the consumer's perspective. But coverage is again an issue. Power transmission and distribution losses for the most recent years are available for about 90 of 153 developing countries. For earlier periods coverage drops even more.

In telecoms, we rely on telephone faults as our proxy for technical quality. Telephone faults are defined by ITU as "reported faults per one hundred telephone mainlines." Compared with ITU's indicators of access and affordability, coverage of telephone faults is rather low. We have data for about 60 of 153 developing countries. An additional problem with phone faults is that they include only reported faults, which is sometimes misleading (especially in countries with bad reporting systems).

Regarding water, no technical quality indicators are available at the country level. The few available indicators from the consumer's perspective (like hours of water supply) have very low coverage. Unfortunately, due to the lack of data, we were not able to analyze the impact of reform policies on water service quality.

\subsection{Basic data analysis}

The evolution of technical quality between 1990 and 2002 differs from electricity to telecoms (Table 9). In electricity, average losses increased by 13 percent, while in telecoms average faults dropped by 57 percent. However, it is important to keep in mind that these two indicators are reported by firms. Improvements in reporting and auditing systems may increase the reported figure, even if the quality of the service has not deteriorated.

Table 9 Evolution of average technical quality, 1990-2002

\begin{tabular}{|lccc|}
\hline & Average & $\begin{array}{c}\text { Standard } \\
\text { deviation }\end{array}$ & $\begin{array}{c}\text { Number of } \\
\text { observations }\end{array}$ \\
\hline $\begin{array}{l}\text { Power transmission and distribution losses (percentage } \\
\text { of output) }\end{array}$ & & & \\
\hline 1990 & 15 & 9 & 72 \\
\hline 2002 & 17 & 11 & 89 \\
\hline Telephone faults per 100 mainlines & & & 45 \\
\hline 1990 & 98 & 86 & 62 \\
\hline 2002 & 42 & 39 & 6 \\
\hline
\end{tabular}

Source: Authors' calculations using data from WDI.

Reform policies, such as IRAs and PPI, may have influenced the service quality and/or the efficiency of reporting systems. Table 10 relates technical quality to reform policies by presenting averages for different country groups according to whether or not reforms were adopted. There seems to be no difference in power losses between countries that committed fully to reforms and those that did not (columns 1 and 4). In contrast, telephone faults are 50 percent lower in countries that have reformed than in those that lack an IRA and in which the telephone company remains state-owned. Regarding countries that have partially committed to reforms (columns 2 and 3), in both electricity and telecoms, those that have an IRA but not PPI show poorer quality performance than 
those that lack IRA but have PPI. The difference is more pronounced in electricity than in telecoms.

Table 10 Quality vs. reform policies in 2002

\begin{tabular}{|c|c|c|c|c|c|}
\hline & \multicolumn{5}{|c|}{$\begin{array}{c}\text { Average } \\
\text { (standard deviation, number of observations) }\end{array}$} \\
\hline & 1 & 2 & 3 & 4 & 5 \\
\hline & $\begin{array}{l}\text { No IRA } \\
\text { No PPI }\end{array}$ & $\begin{array}{c}\text { With IRA } \\
\text { Without PPI }\end{array}$ & $\begin{array}{l}\text { Without IRA } \\
\text { With PPI }\end{array}$ & $\begin{array}{l}\text { With IRA } \\
\text { With PPI }\end{array}$ & All countries \\
\hline $\begin{array}{l}\text { Power transmission } \\
\text { and distribution losses } \\
\text { (percent of output) }\end{array}$ & $\begin{array}{c}18 \\
(13,33)\end{array}$ & $\begin{array}{c}16 \\
(10,21)\end{array}$ & $\begin{array}{c}12 \\
(8,2)\end{array}$ & $\begin{array}{c}18 \\
(10,29)\end{array}$ & $\begin{array}{c}18 \\
(11,85)\end{array}$ \\
\hline $\begin{array}{l}\text { Telephone faults } \\
\text { (reported faults } / 100 \\
\text { mainlines) }\end{array}$ & $\begin{array}{c}63 \\
(55,7)\end{array}$ & $\begin{array}{c}41 \\
(40,20)\end{array}$ & $\begin{array}{c}39 \\
(26,3)\end{array}$ & $\begin{array}{c}32 \\
(29,25)\end{array}$ & $\begin{array}{c}40 \\
(37,55)\end{array}$ \\
\hline
\end{tabular}

Source: Authors' calculations using data from WDI.

Note: For some indicators, coverage in 2002 is not as good as coverage for previous years. Thus, for some groups samples are too small to draw significant conclusions. IRA refers to the existence of an independent regulatory agency; PPI refers to the presence of private participation.

Overall, the basic data analysis implies that quality is improving over time in telecoms but not in electricity. Technology is probably a relevant factor. More surprising, perhaps, is the sense that reform policies do not seem to be related to quality improvements in electricity, whereas they do appear to be related to quality improvements in telecoms.

\subsection{Econometric analysis}

The econometric work reported in Table 11 casts doubt on the conclusions reached from the basic data analysis. However, the diagnostics provided by the econometric analysis are not as reliable for quality as they were for access and affordability. For one thing, the coefficients for the regressions are much less robust-a consequence of the much weaker data coverage, in particular for electricity. Overall, the regressions yield poor results, and our model has a much lower explanatory power for quality than for the other two dimensions of performance. Only the income and the trend variables are significant for both sectors and for a few of the policy variables.

The marginal effects suggest that the creation of an IRA is associated with a statistically significant deterioration in the quality indicators for both electricity and telecoms, and that PPI is not associated with any statistically significant effect on quality in either sector. These are two quite unexpected results. As mentioned earlier, two explanations are possible: (i) performance got worse or (ii) the measurement of actual performance improved with the creation of an independent auditor. In the second case, the apparent deterioration simply reflects better statistics; actual performance may even have improved. 
Table 11 Econometric results for quality, 1990-2002

\begin{tabular}{|c|c|c|c|}
\hline & & $(\mathbf{1})$ & $(2)$ \\
\hline & & $\begin{array}{l}\text { Ln power T\&D losses } \\
\text { (percent of output) }\end{array}$ & $\begin{array}{l}\text { Ln phone faults } \\
\text { (reported faults/100 mainlines) }\end{array}$ \\
\hline \multirow[t]{2}{*}{ (1) } & IRA & 0.121 & $0.767^{\star \star \star}$ \\
\hline & & {$[1.32]$} & [3.67] \\
\hline \multirow[t]{2}{*}{ (2) } & Privatization & -0.043 & 0.201 \\
\hline & & [0.43] & [1.14] \\
\hline \multirow[t]{2}{*}{ (3) } & IRA * privatization & 0.032 & -0.072 \\
\hline & & [0.53] & {$[0.76]$} \\
\hline \multirow[t]{2}{*}{ (4) } & Corruption index & 0.073 & 0.027 \\
\hline & (0=low 1=high) & {$[1.57]$} & {$[0.12]$} \\
\hline \multirow[t]{2}{*}{ (5) } & IRA * corruption & 0.023 & $-1.188^{\star \star \star}$ \\
\hline & & {$[0.14]$} & [3.43] \\
\hline \multirow[t]{2}{*}{ (6) } & Privatization * & 0.196 & -0.262 \\
\hline & Corruption & [1.13] & {$[0.92]$} \\
\hline \multirow[t]{2}{*}{ (7) } & Ln GDP per capita & $-0.115^{\star \star}$ & $0.605^{\star \star}$ \\
\hline & (2000 U.S.\$) & [2.18] & [2.54] \\
\hline \multirow[t]{2}{*}{ (8) } & Ln urbanization & -0.284 & $-2.906^{\star \star *}$ \\
\hline & & {$[1.43]$} & [5.04] \\
\hline \multirow[t]{2}{*}{ (9) } & Time trend & $0.009^{\star \star}$ & $-0.055^{\star \star \star}$ \\
\hline & & {$[2.26]$} & {$[4.76]$} \\
\hline \multirow[t]{2}{*}{ (10) } & Constant & $-14.244^{*}$ & $119.837^{\star \star \star}$ \\
\hline & & [1.83] & [5.59] \\
\hline (11) & Observations & 880 & 652 \\
\hline (12) & R-squared within & 0.23 & 0.39 \\
\hline (13) & $\begin{array}{l}\text { No. of countries in } \\
\text { sample }\end{array}$ & 76 & 85 \\
\hline \multicolumn{4}{|c|}{ Marginal effects } \\
\hline (14) & IRA & $\begin{array}{c}0.140^{\star \star \star} \\
{[4.82]}\end{array}$ & $\begin{array}{l}0.136^{\star \star} \\
{[2.02]}\end{array}$ \\
\hline (15) & PRIV & $\begin{array}{l}0.070 \\
{[1.84]}\end{array}$ & $\begin{array}{l}0.037 \\
{[0.58]}\end{array}$ \\
\hline (16) & CORRUPTION & $\begin{array}{c}0.125^{\star \star} \\
{[2.42]}\end{array}$ & $\begin{array}{c}-0.550^{\star \star \star} \\
{[3.04]}\end{array}$ \\
\hline
\end{tabular}

Absolute value of $t$ statistics in brackets. ${ }^{*}$ significant at 10 percent, ${ }^{* *}$ significant at 5 percent, ${ }^{* \star *}$ significant at 1 percent.

The third marginal calculation suggests that corruption does not have the same impact in the two sectors, even though we find in both cases a statistically significant impact on quality. An increase in corruption was associated with an increase in power losses but with a decrease in telephone faults. Thus, corruption is on average harmful to quality in electricity but beneficial, at least in terms of quality, in telecoms.

The interaction dummies suggest that the reforms have no role in producing the effects of corruption in the electricity sector. In the case of telecoms, the advent of PPI has no effect on the impact of corruption on quality; by contrast, the creation of an IRA does have the expected effect. That is, corruption leads to a deterioration of quality, but the regulator mitigates that negative effect. The dummy for the interaction between IRA and PPI reveals no statistically significant effect. 


\section{Does corruption reveal performance trade-offs for providers?}

Up to now, we have looked at performance indicators one by one. This section offers a perspective on the various indicators in combination, and on how corruption may influence the sectors in the presence of both reforms (IRA and PPI), one reform, or neither reform. Looking at the indicators in combination allows us to examine how operators make trade-offs among the performance dimensions (access, affordability, and quality). Our assessment is limited to the electricity and the telecoms sector, because for the water sector we were able to analyze only one performance dimension (access).

Our chief purpose is to test the extent to which, on average, operators in the two sectors behave as monopolies are expected to behave, that is, whether they try to influence prices, quantity, and quality to increase profits, defined as revenue (i.e. quantities multiplied by prices) minus costs. If reforms restrict one of the performance dimensions - if regulation mandates output or caps prices, for example-operators would be expected to try adjusting the other two dimensions to maintain their profit. For quantity and prices we focus on residential users. The proxy for quality is valid for all users.

The degree to which operators have used corruption to influence any of the three performance dimensions is summarized in Table 12. The table reports the information for countries grouped according to their extent of reform (IRA, PPI, both, or neither). The table is best read down the columns-that is, within a country group and across performance indicators. It can be used to compare, from one sector to the other, how corruption produces higher profit through trade-offs. For example, the effects of lower prices on profits may be offset by lower quality.

In electricity, an increase in corruption in countries with state-owned companies (column 1) is associated with lower residential prices, but also with deterioration in access (quantity) and quality. Countries that have both an IRA and PPI (the reformers in column 4) behave similarly; however, their adjustments to corruption are much larger. Corruption appears to reduce residential prices in reformed countries more than in unreformed ones, but the deterioration quantity and quality is larger as well. One possible interpretation of that result is that IRAs and PPI, when they co-exist in the electricity sector, do not provide better protection against the effects of corruption than no reform at all. The evidence suggests that, from the viewpoint of users chiefly concerned with access, as in most developing countries, adopting only one of the two reforms achieves better results in minimizing the impact of corruption. Indeed, comparing column 1 with column 2, or column 1 with column 3, countries that have an IRA or PPI do not suffer quantity reductions even if they enjoy lower prices. Quality is still adjusted, howeverand much more so when the sole reform is PPI. 
Table 12 Net effects of corruption on utility performance in groups of countries, by extent of reform undertaken

\begin{tabular}{|l|c|c|c|c|}
\hline & $\begin{array}{c}\text { Countries without } \\
\text { IRA and without } \\
\text { PPI (1) }\end{array}$ & $\begin{array}{c}\text { Countries with } \\
\text { IRA but without } \\
\text { PPI (2) }\end{array}$ & $\begin{array}{c}\text { Countries without } \\
\text { IRA but with PPI } \\
\text { (3) }\end{array}$ & $\begin{array}{c}\text { Countries with } \\
\text { both IRA and PPI } \\
\text { (4) }\end{array}$ \\
\hline Electricity & & & 0.003 & -1.108 \\
\hline Quantity & -0.092 & 0.203 & -0.262 & -0.229 \\
\hline Residential prices & -0.159 & -0.126 & -0.269 & -0.292 \\
\hline Quality* & -0.073 & -0.096 & & 0.281 \\
\hline Telecoms & & & 0.571 & -0.486 \\
\hline Quantity & 0.548 & 0.258 & -0.827 & 1.423 \\
\hline Residential prices & 0.756 & 1.097 & 0.235 & \\
\hline Quality * & -0.027 & 1.161 & & \\
\hline
\end{tabular}

Note: The figures are generated by adding the coefficients of corruption (rows 4 to 6 ) for different reform scenarios. To calculate these net effects all coefficients were included, regardless of their significance. All dependent variables are in logs.

* A positive sign means an improvement in quality (a decline in power losses or phone faults).

In telecoms, reforms deal with corruption differently-and apparently more effectively. When corruption increases in countries with state-owned companies, those companies are able to offer higher access but at higher prices and with lower quality (column 1). In contrast, when corruption increases in countries with both an IRA and PPI, companies are able to offer higher access, lower prices, and better quality (column 4). When only IRA is introduced (column 2) there is improvement in terms of quality; whereas when only PPI is introduced (column 3), there is improvement on all three dimensions. It appears, therefore, that in telecoms PPI is more effective than an IRA in dealing with corruption.

This section has demonstrated the usefulness of an integrated perspective when diagnosing the interactions between corruption and reforms. The conclusions reached using the integrated perspective are much more robust than those reached by focusing on the sign and significance of the interaction dummies in the basic model. We have shown that during the period of the study operators dealt rationally with corruption by making simultaneous adjustments in all areas of performance to maximize their profits. The assessment also shows that the most publicized reforms did not work with equal effectiveness in the two sectors. To date, reforms have handled corruption better in telecoms than in the electricity sector.

\section{Concluding remarks}

We have offered three broad new insights in this paper. First, our econometric estimations cast doubt on many of the optimistic impressions, obtained from basic data analysis, of the impact of reforms and corruption on utility performance. In fact, reforms have not always delivered on their promises. While they helped improve some dimensions of performance, they hurt or had no impact on others. Ignoring corruption for the moment, the marginal effects show that establishing an IRA essentially influences all the dimensions of performance relevant to users in electricity and telecoms, but it shows no significant effect in our limited sample of water sector data. The introduction of PPI, 
by contrast, does not have a similar systematic effect across performance dimensions. In electricity it affects only affordability, while in telecoms it affects access and affordability. It has no effect on the quality indicators used here.

Second, to get a better sense of the effectiveness of reform on corruption, it is important to: (i) distinguish countries that have adopted just one of the two reforms from countries that have adopted both, and (ii) to account for all performance indicators simultaneously. When doing so, the results suggest that in telecoms, reforms influence the impact of corruption on all performance dimensions. In electricity, however, they influence the impact of corruption on access and quality. In water, there were no statistically conclusive results-once more, possibly because of the poor quality of the data available.

Third, a look at performance across indicators suggests that the monopolies that deliver utility services behave as theory predicts and "play" with quantity, price, and quality, the three instruments they control to increase their profit margins. On some of these dimensions, corruption also tends to work their way. This may be why the standard reforms have only limited or partial success in offsetting the consequences of corruption in some sectors.

Much work remains to be done to get a clear sense of the impact of reforms and of corruption in the electricity, telecoms, and water sectors. Most important may be the need to generate much better data than the proxies we have used here. However, based on the cross-country information available today, our sense is that increasing PPI or introducing IRAs, while they may help improve access, quality, or affordability in some cases, are not sure bets to make everyone better off overall, contrary to what was hoped for based on theoretical papers about 15 years ago. 


\section{References}

Andres, L., V. Foster and J. L. Guasch. 2006. "The Impact of Privatization on Firms in the Infrastructure Sector in Latin American Countries." Unpublished paper, World Bank and University of Chicago.

Bortolotti, B., and D. Siniscalco. 2004. The Challenges of Privatization: An International Analysis. New York: Oxford University Press.

Boycko, M., A. Shleifer, and R.W. Vishny. 1996. "A Theory of Privatisation.” The Economic Journal 106 (March), 309-319.

Boylaud, O., and G. Nicoletti. 2000. Regulation, Market Structure and Performance in Telecommunications. OECD Economics Department Working Papers 237. Paris.

Brown, A., J. Stern, and B. Tennebaum. 2006. A Handbook for Evaluating Infrastructure Regulatory Systems. Washington, DC: World Bank.

Budds, J., and G. McGranahan. 2003. "Privatization and the Provision of Urban Water and Sanitation in Africa, Asia, and Latin America." IIED Human Settlements Discussion Paper Series (Water 1). London.

Chong, A., and F. Lopez-de-Silanes. 2004. Privatization in Latin America: What Does the Evidence Say?" Economía 4 (2, Spring): 37-111.

Clarke, G., and L. Colin Xu. 2002. "Ownership, Competition, and Corruption: Bribe Takers versus Bribe Payers.” World Bank Policy Research Working Paper Series 2783. Washington, DC.

Clarke, G., K. Kosec, and S. Wallsten. 2004. "Has Private Participation in Water and Sewerage Improved Coverage? Empirical Evidence from Latin America.” World Bank Policy Research Working Paper Series 3445. Washington, DC.

Cubbin, J., and J. Stern. 2001. "Regulatory Effectiveness: The Impact of Good Regulatory Governance on Electricity Industry Capacity and Efficiency in Developing Countries.” Department of Economics Discussion Paper Series 04/04. City University, London.

Dal Bó, E., and M. Rossi. 2006. "Corruption and Inefficiency: Theory and Evidence from Electric Utilities.” Unpublished paper. Universidad de San Andres, Argentina

Estache, A., and A. Goicoechea. 2005. "How Widespread Were Private Investment and Regulatory Reform in Infrastructure Utilities during the 1990s?” World Bank Policy Research Working Paper Series 3595. Washington, DC. 
Estache, A., and M. Rossi. 2005. "Do Regulation and Ownership Drive the Efficiency of Electricity Distribution? Evidence from Latin America.” Economics Letters 86 (2): 253-257.

Estache, A., and E. Kouassi. 2002. "Sector Organization, Governance, and the Inefficiency of African Water Utilities.” World Bank Policy Research Working Paper 3374. Washington, DC.

Fink, C., A. Mattoo, and R. Rathindran. 2001. "Liberalizing Basic Telecommunications: The Asian Experience. World Bank Policy Research Working Paper Series 2718. Washington, DC.

Fink, C., A. Mattoo, and R. Rathindran. 2002. "An Assessment of Telecommunications Reform in Developing Countries.” World Bank Policy Research Working Paper Series 2909. Washington, DC.

Ghosh Banerjee, S., J. M. Oetzerl, and R. Ranganathan. 2006. "Private Provision of Infrastructure in Emerging Markets: Do Institutions Matter?” Development Policy Review 2: 175-202

Guasch, J. L., and S. Straub. 2005. "Infrastructure Concessions in Latin America: Government-led Renegotiations.” World Bank Policy Research Working Paper Series 3749. Washington, DC.

Gutiérrez, L. H. 2003. “The Effect of Endogenous Regulation on Telecommunications Expansion and Efficiency in Latin America.” Journal of Regulatory Economics 23 (3): 257-286.

Hattori, T., and M. Tsutsui. 2004. "Economic Impact of Regulatory Reforms in the Electricity Supply Industry: A Panel Data Analysis for OECD Countries.” Energy Policy 32: 823-832.

Kariuki, M. \& J. Schwartz. 2005. "Small-scale private service providers of water supply and electricity : a review of incidence, structure, pricing, and operating characteristics," Policy Research Working Paper Series 3727, The World Bank.

Kessides, I. 2004. "Reforming Infrastructure: Privatization, Regulation, and Competition.” World Bank Policy Research Report 28985. Washington, DC.

Kirkpatrick, C., D. Parker, and Y. Zhang. 2006. "An Empirical Analysis of the State and Private-Sector Provision of Water Services in Africa.” World Bank Economic Review,

Laffont, J., and T. N'Guessan. 1999. "Competition and Corruption in an Agency Relationship.” Journal of Development Economics 60: 271-295. 
Li, W., and C. Xu. 2004. "The Impact of Privatization and Competition in the Telecommunications Sector around the World.” Journal of Law and Economics 47: 395-430.

Méndez F., and F. Sepúlveda. 2006. "Corruption, Growth and Political Regimes: Crosscountry Evidence.” European Journal of Political Economy 22(1): 82-98.

Pellegrini, L., and R. Gerlagh. 2004. "Corruption's Effect on Growth and Its Transmission Channels.” Kyklos 57(3): 429-456.

Rock, M., and H. Bonnett. 2004. "The Comparative Politics of Corruption: Accounting for the East Asian Paradox in Empirical Studies of Corruption, Growth, and Investment.” World Development 32(6): 999-1017.

Ross, A. 1999. "Does Ownership or Competition Matter? The Effects of Telecommunications Reform on Network Expansion and Efficiency." Journal of Regulatory Economics 15: 65-92.

Ross, A. 2003. "The Impact of the Regulatory Process and Price Cap Regulation in Latin American Telecommunications Markets.” Review of Network Economics 2 (3): 270286.

Shapiro, C., and R. Willig. 1990. "Economic Rationales for the Scope of Privatization. In The Political Economy of Public Sector Reform and Privatization, ed. E. Suleiman Ezra and J. Waterbury (pp. 56-57). London: Westview Press.

Shleifer, A., and R. Vishny. 1993. “Corruption.” Quarterly Journal of Economics 108 (3): 599-617.

Steiner, F. 2001. "Regulation, Industry Structure, and Performance in the Electricity Supply Industry.” OECD Economic Studies 32(1): 143-182.

Vagliasindi, M. 2004. The Role of Investment and Regulatory Reforms in the Development of Infrastructure across Transition Economies. Utilities Policy, 12, pp. 303314

Wallsten, S. 2001. "An Econometric Analysis of Telecom Competition, Privatization, and Regulation in Africa and Latin America." Journal of Industrial Economics 49 (1): 1-19.

Wallsten, S. 2003. "Of Carts and Horses: Regulation and Privatization in Telecommunications Reforms.” Journal of Policy Reform 6 (4): 217-231.

Zhang, Y., D. Parker, and C. Kirkpatrick. 2002. "Electricity Sector Reform in Developing Countries: An Econometric Assessment of the Effects of Privatisation, Competition, 
and Regulation.” Aston Business School Research Papers RP0216. Birmingham, England.

Zhang, Y., D. Parker, and C. Kirkpatrick. 2005. "Competition, Regulation, and Privatisation of Electricity Generation in Developing Countries: Does the Sequencing of the Reforms Matter?” Quarterly Review of Economics and Finance 45 (2-3): 358379. 